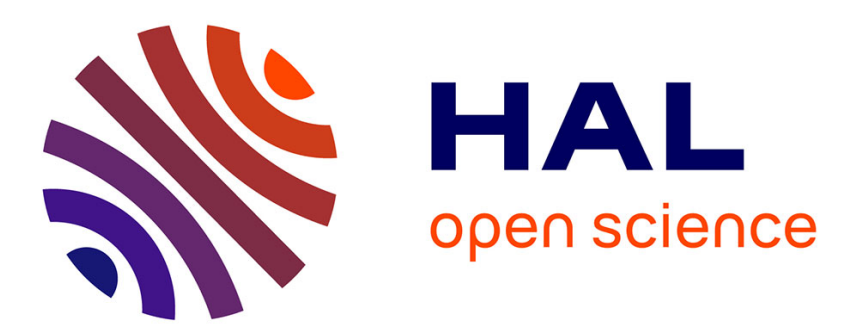

\title{
Integration of the Sustainable Development Evaluation process in Regional Planning: promises and problems in the case of France
}

François Bertrand, Corinne Larrue

\section{- To cite this version:}

François Bertrand, Corinne Larrue. Integration of the Sustainable Development Evaluation process in Regional Planning: promises and problems in the case of France. Journal of Environmental Assessment Planning \& Management, 2004, 6-4, pp.443 - 463. halshs-02544943

\section{HAL Id: halshs-02544943 \\ https://shs.hal.science/halshs-02544943}

Submitted on 16 Apr 2020

HAL is a multi-disciplinary open access archive for the deposit and dissemination of scientific research documents, whether they are published or not. The documents may come from teaching and research institutions in France or abroad, or from public or private research centers.
L'archive ouverte pluridisciplinaire HAL, est destinée au dépôt et à la diffusion de documents scientifiques de niveau recherche, publiés ou non, émanant des établissements d'enseignement et de recherche français ou étrangers, des laboratoires publics ou privés. 


\section{INTEGRATION OF THE SUSTAINABLE DEVELOPMENT EVALUATION PROCESS IN REGIONAL PLANNING: PROMISES AND PROBLEMS IN THE CASE OF FRANCE}

FRANÇOIS BERTRAND* and CORINNE LARRUE ${ }^{\dagger}$

Research Center "Ville Société Territoire"

University of Tours, Citeres UMR CNRS no. 6173, France

*bertrandfrancois@dcemail.com

†corinne.larrue@univ-tours.fr

Received 30 December 2003

Revised 15 October 2004

Accepted 1 November 2004

The paper outlines how the sustainable regional development evaluation process is integrated within the planning and management cycle in the French context. Among the regions that have established reliable evaluation systems, some have tried to incorporate issues relating to sustainable development, thereby complying with European and national demands. But an overview of experiments made in the different French regions shows a wide variety of situations, with no single coordinated procedure allowing comparisons to be drawn. By way of example, the way this integration is implemented in the Nord-Pas-de-Calais region is presented. In this region, political backing, due largely to the presence of green representatives in the regional council, enabled considerable upstream work to be carried out, notably concerning strategic environmental evaluation and policy evaluation with regard to sustainable development. Finally, the paper presents the outcomes of the evaluation process with regard to sustainable regional development: an effect of inter-institutional decompartmentalisation leading to greater transversality have been noticed, as well as a process of an active awareness-raising. But a gap between technical and political levels is still noticeable.

Keywords: French regional planning; regional sustainable development; evaluation process; environmental assessment; structural funds.

\section{Introduction}

The new legal framework that structures French regional planning currently imposes a process of partnership between State administration and Regional governments, and to a lesser extent European and local institutions. It also provides incentives for 
a related process of evaluation at the three stages of the decision-making process (ex ante, mid-term and ex-post evaluation).

The paper will outline (1) how the sustainable regional development evaluation process is integrated within the planning and management cycle in the French context; and (2) by way of example, the way this integration is implemented in the Nord-Pas-de-Calais region; ${ }^{1}$ and finally (3) the paper will present the outcomes of

7 the evaluation process with regard to sustainable regional development. The paper will conclude with the difficulties of such an implementation process, which stem mainly from a predominant technocracy and an inability to overcome "natural" partitioning of the decision-making process.

In France, there is no specific, fixed and generally accepted idea about what regional sustainable development is, and there is also no standardized and definitive system to evaluate the contribution of regional policies aimed at sustainable development. Sustainable development is therefore not a clear principle for action, but is rather an ongoing attempt to reconcile environment and planning. The sustainable development issue should therefore be seen more as a new form of "institutional semantics" (Abélès, 1999) at the crossroads of a number of contemporary schools of thought. With its many-sided nature encompassing conflicting positions, this issue can be considered as "a new rhetorical resource" (Godard, 1994, p. 120), "a new rational and peace-making myth" (Lascoumes, 2000), and a sort of "obligatory gateway" in defining public policy (Rumpala, 2000). Finally, sustainable development must also be seen as a "new professional ideology," providing a large number of actors (experts, assessors, administrators, politicians, etc.) with a new legitimacy for action (Reveret et al., 1998; Lascoumes, 2000). Thus, rather than giving a very precise predefined content to sustainability, we have looked at the form the issues can take through the co-decision-making processes of regional planning programmes.

\section{Regional Policies, Evaluation and Sustainable Development: The French Situation}

\section{The instruments of regional planning and the development of evaluation procedures}

In France, there are two co-existing systems of co-financed regional development policies:

1. European policies relating to Structural Funds (formalized and finalized as a single programming document - SPD).

\footnotetext{
${ }^{1}$ This analysis was conducted within the frame of the thematic network REGIONET.
} 
2. National planning policy, regionalized since the decentralization laws of 1982-1983 (formalized and finalized as Planning Contracts between the State and the Regions - CPER ${ }^{2}$ (Contrat de Plan entre l'Etat et les Régions)).

One of the objectives for the reform of the latest generation of CPERs was to achieve consistency and greater synergy between these two processes by merging the national schedule with that of the Structural Funds Programme.

In relation to these regional policies, the development of evaluation activities in the Regions started about 10 years ago as part of the French and European regional development programmes:

- At the national level through two separate memoranda in December 1993 calling for the development of evaluation ${ }^{3}$ and of environmental evaluation. ${ }^{4}$

- At the European level through the 1993 Structural Funds regulation ${ }^{5}$ stipulat- $^{-}$ ing the requirement to carry out an ex ante evaluation of the proposed policies, particularly with regard to their potential environmental impact. This requirement already existed under the first regulation of 1988 and had no real impact on how the first generation of Structural Funds (1988-1993) was managed, due to lack of time, experience and means. On the other hand, its reaffirmation and strengthening in 1993 acted as a powerful lever to the development of evaluation procedures in the Regions (Goybet, 1998). ${ }^{6}$

The 1994-1999 period thus constituted a phase of gradually setting up the evaluation process, while the next period (2000-2006) should see the maturation of the procedures and practices. In the last 10 years, policy evaluation has been established relatively widely, if unevenly, in the Regions: many evaluation structures have been

\footnotetext{
${ }^{2}$ A Planning Contract has been signed between the State and each French Region.

${ }^{3}$ Memorandum of 9 December 1993 officially introducing regional evaluation procedures for monitoring the State-Region Planning Contracts (CPER).

${ }^{4}$ Memorandum of the Minister for the Environment of 2 December 1993 introducing compulsory environmental monitoring of the Planning Contracts.

${ }^{5}$ EEC Resolution no. 2052/88 modified by EEC resolution no. 2081/93 concerning the assignment of Structural Funds, their effectiveness and coordination of their interventions (article 6). Regulation of Fund coordination: EEC resolution no. 4253/88 modified by EEC resolution no. 2082/93 (article 26). ${ }^{6}$ The lack of time and knowhow of many member States resulted in the absence of prior evaluation for the first European programmes benefiting from Structural Funds (1989-1993), and more generally in an embryonic evaluation procedure. The strengthening of the second European resolution (no. 2081/93/CEE) with the introduction in particular of a conditionality clause (article 26: “. . aid will be granted when ex ante appraisal shows the socio-economic advantages to be gained in the medium term, taking into account the resources mobilised") constitutes "a powerful stimulus to spreading the idea that obligatory assessment was an indispensable step in receiving Community Funds" (Goybet 1998).
} 

created, often attached to strategic management bodies responsible for planning and forecasting (Warin, 1999).

This development of regional public policy evaluation appears to be closely linked to the fact that development and planning policies are more and more systematically designed and managed jointly. These multi-sectoral and co-financed policies are in fact more complex than traditional policies with a clearly identified leader. They are therefore more difficult to manage, supporting the need for an evaluation process aimed at ensuring more rational and transparent management, i.e. ensuring a more even distribution of information to the various partners about policy objectives and implementation. European requirements for evaluation processes are much greater and more precise than those at the national level for the CPERs. This point can largely be explained by the fact that the European level is less involved with the implementation of its programmes and by the significantly larger number of contractors with whom the Commission must deal: Europe is further from the field and manages many more contracts, compensating for these management difficulties by making more demanding requests for information.

In this context, environmental issues of the 1970s and 1980s, followed by the goal of sustainable development in the 1990s, with the related leitmotiv of transversality and cross-sectorality, were particularly well developed in the following areas:

1. Regional development: This is shown in France by the many connections between regional development and the environment institutions, from the outset to the appointment of a Minister for Regional Development and the Environment between 1998 and 2001, and the adoption of a law for regional development in 1999 entitled "Loi d'Orientation pour l'Aménagement et le Développement Durable du Territoire" (Law for Sustainable Regional Development).

2. Evaluation: Seen particularly in the evaluation of the environmental impact of projects (Environmental Impact Assessment, EIA), initiated in 1976 in France and in 1985 at a European level (Dir 85/337/CE). It has more recently been extended to plans and programmes (Strategic Environmental Assessment, SEA Dir 2001/42/CE) and to the recommendations for environmental assessment issued at Rio in 1992 (Principle No. 17 $7^{7}$ ).

These close relationships between sustainable development, joint assessment and management make co-financed regional development and planning an ideal basis to observe how regional policies relating to sustainable development are assessed

\footnotetext{
7 "Environmental impact assessment, as a national instrument, shall be undertaken for proposed activities that are likely to have a significant adverse impact on the environment and are subject to a decision of a competent national authority." (Rio Declaration on the environment and development, United Nations, June 1992.)
} 
1 in practice, even if similar procedures exist at infra-regional (local authorities) and urban levels (especially in the framework of the LA21).

\section{The variety of regional situations}

Among the regions that have established reliable evaluation systems, some have tried to incorporate issues relating to sustainable development, thereby complying with European and national demands. These experimental procedures have not been

7 totally successful, except where there was already a certain acculturation towards sustainable development issues. In other cases, preparation of the new programming period (2000-2006) has provided a starting point for regional procedures for integrating sustainable development.

An overview of experiments made in different French regions shows a wide variety of situations, with no single coordinated procedure allowing comparisons to be drawn. This is also the case in almost all European countries, as has been shown through the work carried out within the Regionet framework. Sustainable regional development procedures thus differ widely, and evaluation methods do not allow inter-regional comparisons. The harmonisation and centralisation role that should be ensured by State departments is very inadequately fulfilled (lack of comparable data, shortage of information about the various regional approaches and actions, etc.).

\section{A national framework}

21 In a memorandum of 11 May 1999, the Minister for the Environment laid down the possible forms of regional development programmes with a sustainable development objective. This statutory text, aimed at regulating the State-Region Planning Contracts also affects European programmes for regional development benefiting has been proposed giving a broad panel of possible sustainability indicators.

The list of criteria given for setting up a process of evaluation and indicators focuses particularly on environmental aspects by setting them apart from other economic and social factors and from decision-making processes (Brodhag and Davoine, 2001) (cf. Table 1).

The approach chosen focuses mainly on improving methods for selecting public actions, by setting up broader regional diagnostic systems (especially the Regional Environmental Profile) and reliable evaluation methods for actions to be taken (matrix evaluation and indicators). This evaluation system is designed both as a decision-making help and as a management, monitoring and assessment tool. However, the different texts are much less explicit about how these tools are to be implemented, and the regulatory provisions are stated more as suggestions 
Table 1. The fields of evaluation according to the memorandum of 11 May 1999.

(a) Draw up an analysis grid for sustainable development

- Time aspect

- Territorial aspect

- Social factor

- Economic aspect

- Management

- Consultation and participation

- Monitoring and planning

(b) Strengthen environmental performance

- land occupation

- Land use

- Waste

- Risks

- Water

- Air

- Preservation of biodiversity

- Life-styles

(c) Initiating policy monitoring indicators

- Transport

- Natural and rural areas

- Energy

- Teaching and research

Source: Memorandum of MATE of 11 May 1999 from Brodhag and Davoine (2001).

than as requirements. In any event, the main emphasis is on recalling the priorities to be respected in the programmes selected for appraisal, i.e. employment, mutual responsibility and sustainable development, plus the impact of the greenhouse effect, ${ }^{8}$ as stated in the Prime Minister's memorandum of 25 August 2000

5 devoted to "implementing the evaluation of contracting procedures for the period 2000-2006."

7 In parallel, a national initiative, more specifically directed towards environmental actions, was launched in connection with the 20 August 2001 circu9 lar, devoted to the mid-term evaluation of the State-Region Planning Contracts and Single Programming Documents, and to the environmental monitoring of pro11 grammes and measures ("mesures"). This memorandum has a general objective of

\footnotetext{
${ }^{8}$ This issue was introduced into the negotiations later through a memorandum of the Ministry of the Environment of 27 August 1999.
} 
1 sustainable development, and therefore adopts a more pragmatic position, putting forward a more realistic method of what should be covered in an environmental assessment. This method is based on three points, of which the first two should have been put into effect when the memorandum was published (which was far 5 from being the case in the Regions):

1. Diagnosis of the environmental issues in the region resulting from the Regional Environmental Profile (REP) and the regional contribution to the public service plan for natural and rural areas (SSCENR): this constitutes both an initial state of the environment in the region, providing a benchmark for future assessments, and a synthesis of the specific environmental issues at the regional and infra-regional levels.

2. An ex ante environmental evaluation carried out during the preparation of the State-Region contracts and programmes applying for Structural Funds. This evaluation is an indispensable prerequisite for all other mid-term evaluation procedures.

3. The dashboard for environmental monitoring of CPER actions and European programmes.

Under the heading of "dashboard for monitoring actions with environmental impact," the third point includes both monitoring environmental programmes and monitoring the effects on the environment of other programmes. It heralds the establishment of a monitoring and assessment tool combining all the financial, production and result indicators for environmental programmes in a computer model called OSEE (Outil de Suivi pour l'Evaluation Environnementale). Having identified the procedures and actions that are likely to require monitoring because of their serious effect on the environment, it also proposes the indicators and potential ecoconditional criteria relevant to the environmental concerns of the region, based on national recommendations. As noted above, the tone is more one of invitation and suggestion than authoritarian obligation.

\section{Evaluating Co-financed Regional Programmes: The Example of the Nord-Pas-de-Calais Region}

31 By way of example, we present below the results of these procedures in a French region that has been a pioneer in this domain — the Nord-Pas-de-Calais. In this Region, political backing, due largely to the presence of green representatives in the regional council, enabled considerable upstream work to be carried out, notably concerning strategic environmental evaluation and policy evaluation with regard to sustainable development (Region Nord-Pas-de-Calais, 2004). 
The Nord-Pas-de-Calais region is a pioneer in France for its integration of environmentally related and sustainable development issues. In 1996, it initiated discussion between the Departments of the Regional Council and the State about the issue of evaluating environmentally related regional policy. Between 1997 and 1999 it carried out a methodological study into evaluating the impact of the actions of the Planning Contract. Inter-departmental work, begun in 1999 within the Regional Council with the help of an outside consultant, led to the drawing-up of an analysis matrix for regional policy composed of 30 criteria, each one accompanied by a series of questions. After an experimental stage, the associated questions were cut down and simplified to make the matrix easy to manage and use. Table 2 gives the list of 30 indicators on this matrix dating from 2001. Using this matrix, specific regional policies could be analysed. It also made it possible to assess the extent to which the different items in the grid appeared in the regional system for monitoring the Planning Contract in the Region.

Similarly, the evaluation programme of the Nord-Pas-de-Calais CPER with regard to sustainable development planned for the 2000-2006 period appears to be extremely well developed compared to other French Regions (cf. Box 1).

From the outset, the acculturation, sensitisation and accountability of all the staff involved in the regional programmes affected by the evaluation system (interdepartmental consultation and transversality) were seen as playing as important a role in the procedure as the actual official results of the appraisal.

More precisely, for the SPD, the programming supplement specifies the exact conditions for implementing and allocating the Funds. Sustainable Development indicators are found under "Procedures," in a paragraph concerning the respect of sustainable development issues and equal opportunities. The sustainable indicator(s) chosen has/have a bearing either on equal opportunities, or on the environment, or both.

Next, project-selection criteria, particularly environmental, are introduced at the level of "Sub-procedures." The importance of each "eco-conditional" criterion is indicated by different status: "priority," "financial bonus" - covering the extra cost of integrating the environment (such as application of the HEQ (High Environmental Quality) standard for building projects) — or "conditional" (in italics in Table 3).

The two procedures converge to a certain extent, if only in the structure of the European (SPD) and national (CPER) programming documents. This common structure facilitates simultaneous reading of these programmes, which are frequently difficult to follow. The same phenomenon can be observed with regard to the evaluation systems that have been set up: the simultaneous preparation of the various programmes, and the fact that certain State departments managed both procedures, provide a certain consistency in the way they are written, particularly by using many 
Table 2. Analysis matrix showing the coherency of regional policies with sustainable developmentRegional council of Nord-Pas-de-Calais.

\author{
Meeting human needs \\ 1. Improving the quality of services and facilities \\ 2. Making services and facilities available for all departments \\ 3. Personal responsibility and autonomy \\ 4. Increasing community spirit within the target population \\ 5. Personal qualifications and social integration \\ 6. Diversification of socio-cultural activities \\ 7. Consideration of spatial equity \\ 8. Consideration of long-term needs \\ 9. Fight against poverty \\ 10. Consideration of social costs
}

\title{
Management of the environment
}

11. Controlling non-renewable resources

12. Limiting pollution and nuisances

13. Enhancing natural wealth and biodiversity

14. Controlling urban spread

15. Developing clean and simple technology, and/or quality-controlled products

16. Observing and anticipating events

17. Accounting for environmental costs

\section{Economic development}

18. Improving economic production and better distribution of capital gains

19. Strengthening employment assets

20. Developing "community business"

21. Instigating and developing alternative economy initiatives

22. Diversifying economic activities

23. Looking for better control of expenses

\section{Participation/governance}

24. Citizens' involvement, and recognition of their contribution

25. Setting up diagnostic procedures prior to action

26. Experience-sharing between actors and pooling of knowledge

27. Matching means with actors; non-competitive actions

28. Qualifications of partners and long-lasting partnerships

29. Recognizing all skills within the region (transversality) during programming, implementation and monitoring phases

30. Implementing the evaluation procedure and taking account of the results

Source: DPE, Regional council Nord-Pas-de-Calais, April 2001.

of the same results and performance indicators for SPD and CPER. One could think that having the same indicators would be an obvious requirement for a minimum 
Box 1 Evaluation programme in the Nord-Pas-de-Calais region.

In the Nord-Pas-de-Calais region, evaluation is carried out in partnership with the State and the two departments who signed the Planning Contract. The evaluation is common to different partners; one evaluation structure bringing together the State, the regions and the two departments has thus been created (...)

A multi-year evaluation programme of the Planning Contract was drawn up for the years 2001-2003 and 2004-2006. It comprises four types of work:

- Transversal evaluations with regard to the four selected priorities: the environment, social equity, employment and territorialisation.

- Thematic evaluations of an objective or means of action: for the 2001-2003 programme, this involved business creation and transmission, tourism, water and agriculture, community actions for export. These choices were accepted by all the partners, with a different leading house for each theme: the Pas-de-Calais department for tourism, the Nord department for water and agriculture, the State for business creation and transmission and the Region for export. Other themes were chosen for 2004-2006: technology transfer, new IT and communication techniques, regional urban policy, intermodal transport.

- Evaluation of a major operation. For 2001-2003 the following themes were selected: "summer quarters" (promotion of social and cultural activities) and cyber-centres. For 2004-2006 the planned theme is the evaluation of the European multimodal platform at Dourges.

- Methodological work aimed at improving evaluation. This involves in particular improving the reliability of indicators and interlinking data bases.

Extracts from report to the National Assembly on the evaluation of public policies and indicators of SD (Duron, 2002).

of rationality. However, it represents a major advance compared on previous practices.

$7 \quad$ The analysis carried out here is based on the evaluation systems as they have been proposed, and our work did not concern their effective implementation, i.e.

9 their operational level. The ex post evaluation, will show how realistic the proposed systems are. However, the fact that the management system of the CPER goes into

11 less detail and does not include eco-conditional criteria as such does not mean that it should be judged as being less effective, or as being less concerned with

13 sustainability than the system set up for the Structural Funds. What the European assessment system gains in precision it loses in inflexibility.

15 In the same way, the appropriation of the evaluation system by the actors responsible for the programmes represents one of the advantages, if not the greatest, of 17 setting up a procedure for evaluating respect for sustainable development. It also constitutes an essential guarantee of the effectiveness of the assessment procedure 19 itself (information derived from indicators, etc.). In this context, while the European evaluation system seems to be more finely tuned and formalized, it is also 
Table 3. Extract of the assessment and monitoring tool of the SPD (Single Programming Document) Objective1 (Phasing Out) of the Nord-Pas-de-Calais Region for the period 2000-2006.

\section{Example: Line of Action III — Redefining and enhancing the region}

Sub-axis 3: Enhancement of tourism and culture

Procedure 7 - Attraction for tourism

One indicator of main result

Sustainable development Indicators:

- Number of operations complying with the European charter of sustainable development

- Number of projects incorporating environmental concerns

Sub-Procedure 7.1: Development of tourism facilities of regional interest

One indicator of main result, five indicators of additional results, One performance indicator:

Criteria for selecting operations: The accepted projects should:

- Be the subject of a general agreement and be consistent with and complementary to other projects in the area

- Be the driving force of endogenous development and exemplary in terms of sustainable development (respect of the environment, all-year, etc.)

- Create activities and jobs

- Provide proof of their viability (market research, etc.)

- Open to the widest possible range of clients including the most disadvantaged

Environmental criteria: In order to improve the environmental quality of the tourism facilities, the following should be encouraged:

— Incentives for projects respecting the environment through exceptional actions (HEQ standards, etc.) (Financial bonus)

- Respect for local architecture and natural heritage, and quality of surrounding landscape (Priority)

- Operations in Natural Park area which comply with the European Charter of Sustainable Tourism (Eligibility a priori)

— Conservation of natural areas (Conditional eligibility)

Source: Programme supplement of SPD Objective 1 transitional support — Nord-Pas-de-Calais.

1 more mandatory and tightly controlled, which provides less incentive for sharing and working in partnership. The CPER management may be less detailed, but it is perhaps better adapted, more appropriate and realistic, and therefore more effective.

\section{Links between European and national procedures}

5 At the regional level, the regional State departments represent the institutional link between the two procedures, because they are the only instructing departments com-

7 mon to the Structural Funds and the CPER. There is therefore an indirect influence between the Regions and Europe, with State departments as mediators, hence the

9 strategic importance of their involvement. 
Another category of actors involved in the evaluation and integration of sustainable development, not shown in Table 3, but who play a key role in acculturation and in disseminating a common doctrine, are the experts (academics and more especially consultants). In response to requests from the funding organisations, they fulfil a popularisation and coordination role within departments. It is often the same experts who are called upon by both the Regional State departments and the Regional Council, thereby fulfilling the important role of bringing the two together. Moreover, their influence lies also in carrying out a linking and capitalisation function between the different Regions. Thus, they have both an inter-institutional role of harmonising the different procedures at a regional level and an inter-regional role of disseminating and sharing regional experiences.

Finally, "bridging structures," by coordinating and putting forward ideas, have an acculturation and mediation function at the regional level about the issue of sustainable development. These structures can be para-regional (such as the ARPE Regional Environment Agency ${ }^{9}$ — which represents the Regional Council of Midi-Pyrénées, and the RAEE - Rhône-Alpes Energie Environnement $\left.{ }^{10}\right)^{11}$ or 17 bipartite, shared by the State and the Regions (such as the CERDD - Sustainable Development Resource Centre - in Nord-Pas-de-Calais ${ }^{12}$ ).

\section{Linking the evaluations made at different times}

Ideally, a well-carried out ex ante evaluation, providing information about the initial state and elements for measuring the desired progress or possible negative impacts, largely determines the course of the other assessment phases. Surveys carried out in 2000, 2001 and 2002 (cf. Table 4) showed that not all the French Regions had at their disposal ex ante evaluation processes for the environment, even though the programmes were already well underway. The mid-term evaluations currently being carried out simultaneously for the European and national programmes may allow a harmonisation of the situation.

A closer look at the regional preparation period of the CPER and SPD (1999-2000) shows that it was an extremely busy period in terms of regional development: in addition to these two programmes, other regional planning documents

31 with indicative goals were being prepared (National plans for collective services such as transportation, rural areas, etc. — Schémas de Services Collectifs, SSC — by

\footnotetext{
${ }^{9}$ Agence Régionale Pour l'Environnement, www.arpe-mip.com.

10 www.raee.org.

${ }^{11}$ About 10 such regional agencies exist in France, grouped together in the RARE - Réseau des Agences Régionales de l'Energie et de l'Environnement - (Network of Regional Energy and Environment Agencies); www.rare.asso.fr.

${ }^{12}$ Centre Ressource du Développement Durable, www.cerdd.org.
} 
Table 4. Progress of preliminary environmental evaluation of the CPER 2000-2006 (data collected in 2000 \& 2002).

\begin{tabular}{|c|c|c|}
\hline \multicolumn{3}{|c|}{ Production of the PER (Regional Environmental Profiles — environmental appraisal) } \\
\hline & Beginning of 2000 & End of 2002 \\
\hline \begin{tabular}{|l|} 
Alsace \\
\end{tabular} & In progress & In progress \\
\hline Aquitaine & No & In progress \\
\hline Auvergne & In progress & $\mathbf{X}_{(2000)}$ \\
\hline $\mathrm{B}^{\mathrm{sse}}$-Normandie & $\times(12 / 99) *$ & $\mathbf{x}_{(2001)}$ \\
\hline Bourgogne & & $\mathbf{X}_{(2001)}$ \\
\hline Bretagne & SSCENR diagnosis & $X_{(2000)}$ \\
\hline Centre & In progress & $\mathbf{X}_{(2000)}$ \\
\hline Champagne-A. & SSCENR diagnosis & $\times(2002)$ \\
\hline \multicolumn{3}{|l|}{ Corse } \\
\hline Franche-Comté & In progress & \\
\hline $\mathrm{H}^{\mathrm{te}}$-Normandie & In progress & $\mathbf{X}_{(2000)}$ \\
\hline Île-de-France & No & \\
\hline Languedoc-R. & & $\mathbf{X}_{(2001)}$ \\
\hline Limousin & $\times(07 / 99) *$ & $x$ \\
\hline \begin{tabular}{|l|} 
Lorraine \\
\end{tabular} & $\times(04 / 00) *$ & $x$ \\
\hline \begin{tabular}{|l|} 
Midi-Pyrénées \\
\end{tabular} & SSCENR diagnosis & In progress \\
\hline Nord-Pas-de-Calais & In progress & $\times(2000)$ \\
\hline P.A.C.A. & Diagnosis of 2 DTA & $x$ \\
\hline \begin{tabular}{|l} 
Pays de la Loire \\
\end{tabular} & In progress & In progress \\
\hline Picardie & In progress & $x_{(2001)}$ \\
\hline \begin{tabular}{|l} 
Poitou-Charentes \\
\end{tabular} & Internal diagnosis & \\
\hline Rhône-Alpes & & $\mathbf{X}(2000)$ \\
\hline
\end{tabular}

Key: Shaded portions are regions where several elements indicate that a region has initiated a drive towards environmental evaluation.

* "Pilot" regions drawing up PER with three separate consultancies (Lerond, Adage environnement et BCEOM).

Source: First column at beginning of 2000 (Bertrand, 2000, p. 25) after telephone survey of the Diren, Sgar and Regional Councils (February-March 2000). Empty boxes indicate the Diren could not be contacted. Second column at end of 2002 (Adage Environnement, 2002).

SSCENR, Schéma de Services Collectifs des Espaces Naturels et Ruraux (Collective National Plan for Natural and Rural areas).

the Regional State departments, and Regional Plans for territorial planning — Schémas Régionaux d'Aménagement et de Développement du Territoire, SRADT — by 3 the Regional councils). This situation led to a trend of "administrative recycling," particularly for regional environmental appraisals: once these have been carried out sufficiently for the SSC, they can be used as a Regional Environmental Profile (Profil Environnemental Régional - PER), a synthetic and strategic appraisal of the regional environmental situation required for preparation of the CPER. This "administrative recycling" trend was evidently used to the full between the regional 
preparation of the CPER and the SPD, mainly, but not only, going in the direction from the Planning Contract to the SPD. ${ }^{13,14}$ It was also used for forthcoming documents (e.g. SSCENR - National plan for rural areas - and SRADT).

\section{Environmental assessment as a driving force for the evaluation of sustainable development}

As a direct consequence of the limited development of environmental assessment during the period 1994-1999, integrating environmental assessment into regional and development strategies remains very limited. This limited development was due to the lack of useful information available at the right time. Thus, when looking at Table 4 for the beginning of 2000, it can be seen that only three PERs had been produced in time to play a real role in drawing up regional strategies (which does not mean that they actually did so), having received specific support for this purpose. ${ }^{15}$ However, a less formal analysis shows that eight out of 18 regions questioned had in fact carried out an environmental appraisal, if sometimes limited or incomplete.

However, Table 4 shows the extent to which environmental appraisal has been carried out in various regional situations, and at the same time indicates a significant gap between the time the decision was made and approved and when the documents for the preliminary environmental assessment were drawn up (sometimes a gap of several years). This situation is not unique to the programmes studied, and is to be found in most strategic environmental evaluation procedures. At the practical level, all our observations lead to the conclusion that there is a flagrant gap between evaluation and decision, i.e. between the evaluation processes and the decision processes which they are supposed to inform (Lascoumes, 1999, p. 24).

However, it is also important not to overlook the fact that this first full-scale trial of environmental assessment has provided an opportunity to set up a package of new measures, collaboration and approaches aimed at improving the integration of environmental concerns into regional development policies. This trend seems to have got off to a slow start, to a greater or lesser extent and in varying forms according to the region. A large number of diagnostic documents have been, or are being produced, indicating that environmental assessment is coming into being in the form of administrative documents, in general with these having no direct influence on

\footnotetext{
${ }^{13}$ Thus, in Nord-Pas-de-Calais, the earlier preparation of SPD Objective 1 was able to be used in some preparatory work for the Plan contract.

${ }^{14}$ Thus, in Nord-Pas-de-Calais, the earlier preparation of SPD Objective 1 was able to be used in some preparatory work for the Plan contract.

${ }^{15}$ The three regions were those chosen as pilots to test this first preliminary environmental evaluation system.
} 
1 the decision-making process. However, an indirect effect can occur via the actors involved in the evaluation process (educational self-learning function ${ }^{16}$ ). This environmental evaluation experience will undoubtedly allow: (1) a greater visibility at a political level of the environmental concerns and issues; (2) clarification of hazily perceived issues; (3) recognition of new areas of intervention, up to now largely ignored; (4) approval of new public actions taken for newly identified problems. Environmental evaluation could thus fulfil a role in the emergence, construction and legitimisation of new issues (Bertrand, 1999). The development of evaluation 9 procedures could thus help endorse the implementation of environmental policies, by justifying their necessity (Lascoumes, 1994), particularly by raising the awareness of the actors involved.

For the moment, the two procedures of decision-making and evaluation appear to have no formal connection. The circulars dated 11 May 1999 (Minister of the Environment) and 25 August 2000 (Prime Minister) lay down, respectively, the form of environmental assessment and the general evaluation of the CPER, while the CPER were actually prepared between July 1998 and July 1999, mainly at the beginning of 1999. Additions to the programme detailing the implementation and follow-up of the contracts were drawn up in 2000.

However, experience shows that if assessment practice and skills are well developed, they can play a significant role, together with the departments involved, when a suitable event endorses and legitimises it. ${ }^{17}$

\section{The Effects of the Evaluation Process on Planning Exercises}

The dynamics of implementing regional development programme assessment relating to the environment and sustainable development have produced institutional innovations. These may be formal, such as the creation of new structures within departments for assessing the environment and/or sustainable development. They can also be innovations in how funded actions are handled, such as the adoption of eco-conditional criteria in SPD objective 1 for the Nord-Pas-de-Calais.

\footnotetext{
16 “...) the contribution of the evaluation is more marked and deeper at an administrative level: as a means of clarifying the issues; as a broader reflection of fragmented public action; as a space for confronting isolated rationalities; even as a means of instigating cooperation, always called for and rarely seen. For most administrative agents involved in the evaluation, there is a strong impression of learning and of a relatively irreversible trend forwards." (Lascoumes and Setbon, 1996, pp. 61-62.)

${ }^{17}$ This was the case, for example, when the first reading of the Docup Objective 1 was turned down by the European Commission in Nord-Pas-de-Calais, leading to the monitoring and assessment procedure for the environment to be expanded.
} 
An effect of cross-sectoral integration (within an organisation)

These institutional innovations are essentially informal, with cross-sectorality, even temporary, brought about by the transversality required in practice to draw up common points of reference and establish indicators for several areas of action. Due to the scope of the issues dealt with, the technical preparation of the regional planning exercises by programmes such as the SF and the CPER require in depth consultation between departments. When the contribution of policies concerning sustainable development has to be evaluated, many questions are raised and discussion can no longer be carried out on a sectoral basis. It thus becomes essential to learn to work together, to analyse potential actions from different perspectives and understand the constraints of other departments. In practice, these transversality exercises often prove to be as enriching as they are difficult, arousing a reaction and the interest of the staff concerned. It therefore constitutes a process of active awareness-raising.

On this point, the involvement of different instructing departments is decisive. While access to outside consultants can lead to improved coordination, contracting out the work of defining the relevant features and indicators will not have the same impact at all in terms of inter-departmental coordination or the staff's eventual appropriation and involvement in the sustainable development issues.

With regard to setting up the evaluation system for the CPERs and SPDs for the 2000-2006 period, success in integrating features linked to sustainable development depended to a large extent on the level of regional involvement in the issue that already existed. Unprepared departments sometimes perceived the injunction for sustainable development, which arrived with no explanation or discussion, as a hollow imposition. However, the amount of work involved in preparing the programme and the high profile given to the issue of sustainable development resulted in a raising of awareness and the instigation of discussions around the subject of how sustainable development could be incorporated into actions undertaken.

Inter-departmental decompartmentalization could be more difficult for the State departments, which are essentially organized vertically, than for the Regional Council departments, which are de facto less compartmentalized and more integrated. These difficulties have been particularly acute for the most autarkic bodies, which are not used to cross-sectorality (e.g. state education), and which can see the intrusion of other concerns into their policies as a loss of authority.

The awareness-raising and internal training of staff involved may appear the most significant outcome in setting up the evaluation measures and procedures. As a result, the ability to develop policies is modified, with a trend towards those policies that are more appraising and have incorporated environmental concerns. 
1

\section{The effect of inter-institutional decompartmentalisation leading to greater transversality}

The very nature of jointly run development policies can lead to inter-institutional decompartmentalisation. The assessment of programmes such as the CPER is necessarily carried out in partnership. Assessment of the Structural Funds proves to be significantly less open, as it is carried out within the regional State departments alone.

\section{An absence of vertical integration}

With regard to the evaluation process, there seems to be virtually no vertical integration. The movement seems to be top-down, with more or less authoritarian duties imposed by the upper levels (obligations of the European Commission, suggestions from the State). After that, the upper levels only intervene to check the progress at mid-term. Thus, the role of the upper levels of coordinating, centralizing and disseminating good practices appears to be only partially fulfilled. Moreover, the responsibility for assessing national and European regional development policies is different in the two bodies. ${ }^{18}$ To lessen the impact of these points, a public policy assessment website has been created on the joint initiative of these two bodies. ${ }^{19}$

\section{The hypothetical public participation}

With regard to public participation, there is not at the moment any real association of inhabitants for these procedures at the regional level. Moreover, there does not seem to be any real involvement as yet as a result of disseminating the assessment results. However, this point is linked to the complexity of implementing these programmes and to the strategic level in which they have become established. However, in some Regions there have been consultation experiences prior to preparation of the CPERs, often just basic information-giving sessions, but sometimes more (regional conferences, opinion polls, electronic forums, etc.). To conclude, public participation is still almost non-existent (at best it is limited to information). There is no real translation of discussion about citizenship and governance into concrete actions.

\footnotetext{
${ }^{18}$ Evaluation of the regional policies funded by SF is coordinated by the Delegation for Regional Development and Regional Affairs (Datar) while assessment of the CPERs is under the responsibility of the Commissariat Général au Plan - (CGP).

${ }^{19} \mathrm{http}: / /$ www.evaluation.gouv.fr. Its objective is to "facilitate access to the greatest number (actors in assessment, the media, researchers, general public) to all the assessment data produced by public bodies."
} 
Bridging the gap between technical and political levels: the necessary political support or technocratic drift

The linkage between evaluation procedures for sustainable development at technical and political levels is different from region to region and seems to depend largely on the political support for the procedure:

1. If elected representatives have initiated or are interested in this linkage, the dynamics are bound to be strong. Bridges will be built between the work carried out at a technical level and discussions being held at a political level, and the dynamics of each group will feed the other. It will then be possible to see a real process of regional appropriation by the elected representatives and by the technicians (as in the Nord-Pas-de-Calais region).

2. On the other hand, if the elected representatives do not really believe in it, or view the procedure with a kindly but distant eye, letting it be because they have no choice, but showing no particular interest, then there will be no bridge between the technical and political levels. There is then a real risk that the procedure will fall into a technocratic ghetto. There can be no solid assessment procedure for sustainable development without political support.

Moreover, the closeness between elected representatives and technicians in the regional authorities does not necessarily facilitate the development of evaluation processes, if there is not a solid support from elected representatives. In general, as this is still frequently seen as an inconvenient and dangerous control tool, its development is therefore viewed with reticence. On the other hand, this phenomenon is much less apparent within the regional state departments, where this is greater distance from elected representatives. They therefore have much greater autonomy in setting up evaluation procedures, especially with regard to the environment and sustainable development.

The question therefore concerns the issue of appropriating sustainable development, at the level of both elected representatives and departments. The ideal objective is that this appropriation be collective and shared. However, the underlying institutional and political stakes direct the process towards competitive appropriation (between departments and between regional authorities). One of the main issues at stake in evaluation is thus to allow the decompartmentalization at work during the conception of joint development policies to continue during their implementation.

\section{Conclusion}

\section{A learning tool}

The widespread application of the partnership process in designing regional development policies involves disseminating and developing the evaluation process as an 
indispensable management tool. Joint planning thus involves evaluation. Analysing the experiences of taking sustainable development into account in assessment procedures shows that these procedures appear to be formative in terms both of sustainable development and of evaluation. Assessment of sustainable development is thus valuable as a learning tool from two points of view: on the one hand, by making regional policy managers aware of and responsible for sustainable development and its implications in the programmes to be implemented; and on the other hand, by taking assessment away from the departments specialised in forecasting and strategies and giving it to all the institutions making up the regional system.

\section{Sustainable development evaluation: a recent movement strongly associated to environmental sector}

In France, regional evaluation and planning procedures for sustainable development are still at an exploratory and experimental stage. The system for managing these practices is recent and still being set up. The involvement of several political and/or administrative actors as leaders seems to be a determining factor. In the same way, linking and coordination functions rely heavily on the role of the experts involved in the process.

The French regions do not have many environmental powers but ensure a variety of coordination, support and experimentation activities in relation to sustainable development. To a large extent, these actions are closely linked to the domains of the environment. Similarly, national policy with regard to sustainable development was set up relatively late, and its institutionalisation has been very tightly associated with the environment sector (ministry). The ministerial naming game has thus passed the environment from the ministry of "Regional Development and the Environment" (1997-2002) to that of "Ecology and Sustainable Development." More recently (July 2004), an inter-ministerial delegation responsible for sustainable development has been created within the government.

Work carried out within the Regionet framework has highlighted that this close institutional proximity between environment and sustainable development is not unique to France and is to be found to a greater or lesser extent in the other European countries. Likewise, Regionet's work has highlighted the importance of the role of experts and intermediary actors in establishing the regional dynamics of sustainable development, and the importance of the human factor and regional specificities (wealth and identity aspects specific to the regions). Finally, the overall work has highlighted the role of coordination and awareness-raising fulfilled by the evaluation processes.

\section{Think Globally?}

In this new and fragile context of the steps taken so far, the extraterritorial dimension, which constitutes an important aspect of the spatialisation of the sustainable 
development issue (Zuindeau, 2000), seems barely to have been integrated. We remain very close to the concept of endogenous development, and other extrateritorial actors appear to have been largely overlooked in the assessment process. The question therefore remains as to whether the assessment process can overcome the serious difficulties concerning the integration of actors who do not have any direct representation, and become a forum where the interests of "weak" actors, such as future generations, non-human species and exogenous actors, can be represented. The answers to this question will depend largely on the political importance given to these actors.

\section{References}

Abeles, M (1999). Pour une exploration des sémantiques institutionnelles. In Ethnologie Française, Les mots des institutions, Tome XXIX, Vol. 4, octobre-décembre, pp. 501-512.

Adage Environnement (2002). Elaboration des enjeux environnementaux des Profils Environnementaux Régionaux, MEDD-D4E, Novembre 2002, 44 pp. + annexes.

Bertrand, F (1999). L'évaluation environnementale ex ante: outil d'aide à la décision et facteur d'intégration de l'environnement dans les pratiques et les concepts d'aménagement du territoire? L'exemple de l'évaluation environnementale stratégique pour la préparation des Contrats de Plan Etat-Région 2000-2006. Mémoire de D.E.A., Maison des Sciences de la Ville, Université François Rabelais de Tours, 107 pp. + annexes.

Bertrand, F (2000). L'évaluation environnementale stratégique des programmes de planification régionale. Analyse du cadre réglementaire français et européens, 10 pp. communication présentée au $5^{\text {ème }}$ colloque des spécialistes en évaluation d'impacts à Paris les $22,23 \& 24$ mai 2000.

Brodhag, C and P Davoine (2001). Evaluation, rationalité et développement durable. In Evaluation et gouvernance, M Basle and C Guignard-Hamon (eds.) pp. 241-254. Société Française d'Evaluation, Actes du colloque de Rennes de juin 2000, Imprimerie de l'Université de Rennes 1. (www.agora21.org).

Duron, P (2002). L'évaluation des politiques publiques et les indicateurs du développement, rapport no. 3594 fait au nom de la Délégation à l'Aménagement et au Développement Durable du Territoire, enregistré le 12 février 2002 à la Présidence de l'Assemblée Nationale (disponible en ligne http://www.assemblee-nationale.fr/rap-info/i3594.asp).

Godard, O (1994). Développement durable: paysage intellectuel. Natures-SciencesSociétés, 4(2), 309-322.

Goybet, P (1998). Le développement de l'évaluation au niveau communautaires. Enjeux et perspectives. In Revue d'Economie Régionale et Urbaine no. 3, pp. 357-368. Évaluation des politiques publiques territoriales.

Lascoumes, P (1994). L'éco-pouvoir, environnements et politiques. Paris: L'Harmattan. 
1 Lascoumes, P (1999). Les nouvelles modalités de la décision publique dans le domaine de l'environnement et la place de l'évaluation environnementale des plans et programmes. In Amenagement \& Nature, pp. 24-26. Evaluation environnementale des plans et programmes, Actes du colloque d'Angers 10-11 septembre 1998, no. 134, septembre 1999.

Lascoumes, P (2000). Les ambiguïtés des politiques de développement durable. Université de tous les savoirs, conférence no. 293, tome 5, éditions Odile Jacob, Paris.

Lascoumes, P and Setbon (1996). L'évaluation pluraliste des politiques publiques. Enjeux, 9 pratiques et produits, Groupe d'Analyse des Politiques Publiques - C.N.R.S., Commissariat Général du Plan, 182 pp.

11 Region Nord-Pas-de-Calais (2004). Le développement durable en question. Etudes Prospectives Régionales no. 8, mai 2004, 101 pp.

13 Reveret, J-P, L Doran, and L Ghanime, (1998). Biodiversity, other diversities and the case for environmental assessment. Communication présentée au $18^{\text {ème }}$ congrès de l'Association International pour l'Evaluation d'Impact, Christchurch, New Zealand, CD ROM IAIA Conferences 1997, 1998, 15 pp.

17 Rumpala, Y (2000), Voies et ambiguïtés du repositionnement de la régulation publique face au développement durable. Esquisses d'analyses à partir du cas français. Intervention du 07/12/2000 au Séminaire Interdisciplinaire sur le Développement Durable, Lille, 22 pp. (www.revue-ddt.org).

21 Warin, P (1999). L'évaluation en région, prisme d'une maturation politique et administrative. CERAT/CNRS — Institut d'Etudes Politiques de Grenoble, 232 pp.

23 Zuindeau, B (ed.) (2000). Développement durable \& Territoires, Presses Universitaires du Septentrion, Villeneuve d'Ascq, 289 pp. 